\title{
Article
}

\section{Investigating the Impact of Competition and Incentive Design on Performance of Crowdfunding Projects: A Case of Independent Movies}

\author{
Li Chen
}

check for updates

Citation: Chen, L. Investigating the Impact of Competition and Incentive Design on Performance of Crowdfunding Projects: A Case of Independent Movies. J. Theor. Appl. Electron. Commer. Res. 2021, 16, 791-810. https://doi.org/10.3390/ jtaer16040045

Academic Editor: Gisela Ammetller Received: 28 October 2020

Accepted: 14 January 2021

Published: 27 January 2021

Publisher's Note: MDPI stays neutral with regard to jurisdictional claims in published maps and institutional affiliations.

Copyright: (c) 2021 by the author Licensee MDPI, Basel, Switzerland. This article is an open access article distributed under the terms and conditions of the Creative Commons Attribution (CC BY) license (https:/ / creativecommons.org/licenses/by/ $4.0 /)$.
Department of Management, Marketing and Entrepreneurship, Broadwell College of Business and Economics, Fayetteville State University, 1200 Murchison Road, Fayetteville, NC 28301, USA; lchen@uncfsu.edu

\begin{abstract}
Recently, crowdfunding has become a popular e-commerce model based on web 2.0 platforms for fundraisers to collect funding from a large group of supporters using the Internet. However, many projects failed to reach their funding targets. Despite the growing interest of academic researchers and e-commerce professionals in identifying drivers of crowdfunding success, important factors like competition and incentive design have not received much attention in prior research. In this study we aim to fill this gap by investigating the impact of competition and incentive design on the performance of crowdfunding projects. Drawing upon literature of entrepreneurship, we develop a research model involving key factors such as competition intensity and the number of reward levels. Using real data of 209 independent movie projects of an online crowdfunding platform, we test the proposed hypotheses of the impact of competition and incentive design on crowdfunding success. Our results show that competition plays a significant role in crowdfunding performance. The higher competition pressure is, the lower performance of crowdfunding projects will be. We also find that factors such as the number of reward levels and the plan of attending movie festivals are essential to the success of crowdfunding projects, but the funding level of getting the top reward does not exert a significant impact. Our study contributes to the e-commerce literature by further exploring the mechanism of crowdfunding success with theoretical explanation and empirical evidence. Researchers and professionals can apply our theoretical findings regarding competition and incentive design in other e-commerce platforms. Furthermore, our results provide useful managerial insights and operational policies for project founders and managers of crowdfunding platforms.
\end{abstract}

Keywords: reward-based crowdfunding; electronic commerce; entrepreneurship; competition intensity; incentive design; crowdfunding success; regression analysis

\section{Introduction}

One of the most critical challenges new ventures face is lack of financing and attention [1-3]. Advances in information technology have created other alternatives such as web 2.0 based crowdfunding platforms for new ventures to raise capital. Crowdfunding can be defined as "the efforts by entrepreneurial individual and groups-cultural, social and for-profit - to fund their ventures by drawing relatively small contribution from a relatively large group of individuals using the Internet, without standard financial intermediaries" [4]. In recent years, crowdfunding has witnessed a rapid growth. According to a recent industry report from Technivio, the crowdfunding market is expected to reach USD 89.72 billion from 2018 to 2022 [5]. Several reasons might explain the quick development and spread of this new model of funding. First, crowdfunding enables entrepreneurs, especially those who may not be eligible for traditional funding due to uncertainty of future revenue or lack of experience, to finance their creative projects [6,7]. Second, crowdfunding helps entrepreneurs to get funded without going through the lengthy procedure of applying for financial investment from banks and financial agencies [1,2]. Third, crowdfunding project founders can have more flexibility in their funding process while being accountable to 
the community [8]. For example, they can decide what information to provide, when to launch their crowdfunding projects, how to design their projects, and how to promote them to attract funding from online crowdfunding platforms. Lastly, stories of successful crowdfunding have attracted continuous attention and participation from entrepreneurs of all kinds [9]. For example, several crowdfunding projects have become successful companies [10].

While major crowdfunding platforms such as Kickstarter, Indiegogo, and GoFundMe can easily incorporate thousands of crowdfunding projects and funders every day, many projects fail to meet their funding targets in time. It is estimated that the overall failure rate of crowdfunding projects is around 40\% [11]. According to Mollick's exploratory study on Kickstarter, the success rate of crowdfunding projects in Kickstarter is 44.7\% [4]. Naturally, one major goal of current academic researchers and professionals is to identify determinants of crowdfunding success. Relevant studies in this line of research have analyzed factors ranging from the role of reward-based crowdfunding model [12], network of project founders [4,13], experience of project founders [14], updates of projects during the crowdfunding duration $[15,16]$, language used to describe the project [17], the role of social identity [18], social capital of project founders $[19,20]$, the role of local community [21], project founders' empowering the community [22,23], location of the project [24], gender of project founders [25], etc.

While these studies offer important insights into the determinants of crowdfunding success, the mechanism of crowdfunding success is still not well understood [21]. Drawing upon literature of entrepreneurship, we argue that competition and incentive design are key factors for crowdfunding success yet receive little research attention. Therefore, we extend the conceptual framework of crowdfunding success by further exploring the new dimension of these factors. Previous studies show that competition has a significant impact on entrepreneurs such as influencing their strategy of entering and exiting the market [26,27]. Intense competition will reduce the entrepreneurs' ability of getting resources [28] and reaching their goals [29]. Competition exerts a similar effect on performance of crowdfunding projects because all projects are open to funders in the platform $[4,30]$. Since resources (financial funding) are always limited, more funding for one project often means less funding for other projects. Therefore, similar to e-commerce practice in which sellers try to engage potential customers, project founders compete to "sell" their projects to potential funders in the crowdfunding process. Promotion of crowdfunding projects might take place outside the crowdfunding platform, such as through other online methods as well as the offline environment [31,32]. In addition, entrepreneurs find that incentives can be a critical factor to involve donators, employees, and the public for new ventures [33-35]. Funders of reward-based crowdfunding projects often receive only non-monetary rewards such as pre-order products or services with earlier delivery or better price [36]. This is different from equity-based crowdfunding whose funders can get monetary income such as a share of the invested company and lending-based crowdfunding whose funders can earn an interest. Therefore, incentive design is a crucial aspect of reward-based crowdfunding to encourage participation and contribution. Furthermore, competition and incentive design are not closely related to previous identified success drivers. Nevertheless, there is a lack of rigorous empirical research on these two factors, not to mention providing useful recommendations for project founders, business administrators, and e-commerce specialists. In this study, we aim to fill the gap by investigating the roles competition and incentive design play in crowdfunding platforms. To be more specific, we intend to answer the following research question: What are the impacts of key factors concerning competition and incentive design on the performance of crowdfunding projects?

Using a unique dataset of 209 independent movie projects, we plan to find an answer to the research question raised above. Our results show that competition and incentive design are essential factors for crowdfunding success. Specifically, the number of competitors, competition intensity, number of reward levels, and plan of attending movie festivals have a significant impact on the performance of crowdfunding projects. We contribute 
to the literature by starting a discussion on the role of these two factors in fast-growing online crowdfunding. So far little research has focused on these factors. We believe our results have demonstrated the critical role of competition and incentive design. In addition, our study offers important managerial insights and operational policies for e-commerce starters, such as project founders, to develop better strategies to cope with competition, reward design, and public incentives. The market of online crowdfunding is undergoing rapid development. By providing project founders with useful managerial insights, we aim to help them better understand this new funding model.

The rest of the paper is organized as follows. Section 2 provides a comprehensive literature review of relevant research. In Section 3, we develop a set of hypotheses related to the impact of competition and incentive design on the performance of crowdfunding projects. In Section 4, we first briefly introduce independent movie crowdfunding and our data collection. We then test the proposed hypotheses with a unique dataset of 209 crowdfunding projects of independent movies collected from one online crowdfunding platform (Seed and Spark). We present the results of regression analysis and discuss the managerial insights based on our empirical analysis. Section 5 presents the theoretical contributions and practical implications of our study. Section 6 concludes the paper with future research directions and limitations.

\section{Literature Review}

\subsection{Literature of Crowdfunding}

Our study is closely related to two research streams. The first stream is the literature of crowdfunding. One group of studies lays the emphasis on models of crowdfunding. For example, Belleflamme et al. compared two models of crowdfunding: Pre-order products or service or profit sharing (equity) [37]. Their analytical model showed that entrepreneurs would prefer pre-order products or service in the case that the initial funding demand is relatively small and would prefer profit sharing otherwise. Cummings et al. analyzed two models of reward-based crowdfunding: Keep-it-All (KIA) or All-or-Nothing (AON) [12]. They found that small scalable projects prefer KIA model while large non-scalable projects prefer AON model. In addition, KIA strategy leads to less risk and less return for entrepreneurs. Chemla and Tinn indicated that reward-based crowdfunding can use a real option to obtain valuable information of consumers' preference [38]. In a recent study, Ellman and Hurkens provided an optimal design for both profit maximization and welfare maximization crowdfunding [39]. Overall, these studies suggest that crowdfunding is a viable solution for new ventures and entrepreneurs to finance their creative projects. However, their findings do not provide detailed insights into the performance of crowdfunding projects.

Another group of studies analyzes crowdfunding based on empirical analysis. At the level of funders, researchers mainly focus on the motivation of crowdfunding backers to contribute. For example, Cholakova and Clarysse [40] and Gerber and Hui [36] reported that crowdfunding backers are motivated by the connectedness to the community of similar interests and desire to help others. Based on a survey of 309 backers of equity crowdfunding, Bretschneider and Leimeister found that recognition motivation and image motivation exerted significant impact on participants' motivation [41]. Additionally, recent research examines backers' involvement in projects (prosumerism) [22,42,43]. For example, Planells analyzed the top 10 most funded gaming projects in Kickstarter and concluded that conversion from consumers to prosumer-investors brings positive influence [42]. Fanea-Ivanovici investigated eight successful Romanian movie crowdfunding projects and found that prosumers serve as a key success factor [22]. Current studies also explored crowdfunding dynamics from the perspective of backers. Block et al. classified new players in entrepreneurial finance, including crowdfunding backers, based on supply- and demandside factors [44]. Block et al. compared two entrepreneurial finance market segments of the future: crowdfunding and initial coin offerings [45]. 
At the level of crowdfunding project, studies on the drivers of crowdfunding success can be classified into two types. The first type examines various factors related to features of crowdfunding projects, while the second type emphasizes features of project founders. For both types of studies, signaling theory is widely used to identify drivers of crowdfunding success. Signals of high-quality projects include experience of project founders [14], updates from crowdfunding founders $[15,16]$, team characteristics and use of media [46], and the language used to describe the project [17] for the first type, and a larger social network [4,13], internal and external social capital of project founders $[19,20]$, and social identity [18] for the second type. Overall, this group of studies provides general strategies related to improving the success rate of crowdfunding projects based on real data. However, factors such as competition and incentive design are overlooked in prior studies.

Our study contributes to this line of research by exploring the key factors of competition and incentive design which have not received much attention in previous research. So far relevant research in this area, especially empirical research, is scarce. Lin et al. used a probabilistic model to examine the dynamic competition among projects in crowdfunding markets [30], but their results are based on simulation. To the best of our knowledge, our research offers, for the first time, a comprehensive empirical analysis to investigate the impact of competition and incentive design on the performance of crowdfunding projects.

\subsection{Literature of Entrepreneurship}

The second stream relates to the literature of entrepreneurship. Due to a lack of theory in crowdfunding competition and incentive design, we build on research of entrepreneurs who are similar to crowdfunding project founders as they all need to address the needs for funding. Prior studies found that competition plays an important role in the survival and development of entrepreneurs [26-29]. For example, Nocke showed that increased active entrepreneurship will increase competition and therefore decrease the profits, which will impact entrepreneurs' strategy of entry and exit [26]. Spulber studied competition among entrepreneurs in three different stages from initial entry stage to final creative destruction stage [27]. Based on data of 943 nascent entrepreneurs, Khan et al. found that perceived competition intensity had an important negative effect on entrepreneurs goal commitment and disengagement [29]. Using a questionnaire of 951 small-sized and medium-sized firms, Hernandez-Carrion, et al. found that competition intensity will reduce entrepreneurs' use of resources [28]. In addition, competition exists in offline environments beyond the crowdfunding platform, during processes such as promotion of crowdfunding projects $[24,32]$ and converting backers to prosumers of the crowdfunding projects [22,42]. Overall, these studies highlight important competition strategies entrepreneurs use in the market. Therefore, project founders need to carefully observe the competition environment and identify applicable strategies such as deciding best timing for entry, growing or exiting the crowdfunding platforms and how to empower the backers and attract them to become prosumers.

Prior research examined the competition due to information cascades as well. Parker suggested that competing crowdfunding projects might lead to information cascades [47]. Vismara also reported this specific effect in equity crowdfunding [48]. He claimed that when there are information cascades in crowdfunding platforms, the uninformed crowd will follow investors with public profiles. As a result, many projects (even good projects) might remain unfunded. Nevertheless, factors related to the competition environment, such as number of competitors and competition intensity, are overlooked in prior studies.

In the literature of incentive design of entrepreneurship, Glaeser and Shleifer pointed out that non-for-profit entrepreneurs should use soft incentives to attract contributions for their projects [34]. Monson et al. developed models for cooperation between employees and entrepreneurs to study the impact of incentive design on new venture participation [35]. Arping et al. examined public financial support for entrepreneurs using a credit guarantee approach [33]. Gneezy et al. found that extrinsic incentives such as monetary rewards might not always work in the long term, such as encouraging participants to make contributions 
to the public good [49]. Mishra and Zachary indicated that entrepreneurs may use the incentive signal to attract investors for high valuation offers [50]. In general, research in this literature stream provides useful references in support of the notion that incentive design plays an important role in attracting funding for entrepreneurs. However, findings in prior studies on monetary reward might not apply to the setting of reward-based crowdfunding in which most funders receive only non-monetary rewards. Therefore, project founders who are eager to improve crowdfunding performance need to carefully consider incentive design factors such as the number of reward levels, and the funding level of getting the top reward.

Drawing upon prior research, our study expands the literature into the context of online crowdfunding platforms in which project founders share similar features to entrepreneurs. While previous studies mainly focus on competition of entrepreneurs for consumers, our research extends the competition into the early stage of fundraising. We have specifically examined key features such as the number of competitors and the competition intensity. Please note that while project founders compete with each other, their projects (independent movies) might not be perfect substitutes due to geographical and cultural difference [51]. In addition, we incorporate a new dimension of incentive design by exploring the number of reward levels, the funding getting the top reward and the plan of attending movie festivals which are understudied but might be closely related to funders' contribution behavior.

Our research is also related to studies of online movies in e-commerce literature. One group of studies mainly focused on the users' online reviews and ratings on movies. For example, Dellarocas et al. found that adding information from online reviews helps increase the forecasting accuracy of movie sales [52]. Peng et al. found that professional critics' reviews are more accurate but ordinary consumers' reviews have more significant impact [53]. Other related issues in this group include the impact of users' reviews on revenue of movies [54], cultural effect in online movie ratings and reviews [55,56], and information cascade in online movie ratings [57], etc. Another group of studies emphasizes consumers of online movies. For example, Jang et al. studied consumers' selection of online media [58]. Other topics include the impact of recommendation agents on consumers' online movie shopping [59], the dynamics between consumers' satisfaction and online movie revenue [60], etc. Our study complements the existing research by investigating the project founders' (movie producers') strategy of using crowdfunding to finance the movies.

\section{Hypothesis Development}

Based on related studies on crowdfunding and entrepreneurship, we explore the key factors of competition and incentive design and their impact on the performance of crowdfunding projects. Competition plays a significant role in performance of entrepreneurs [26-29]. We argue that a similar effect of competition exists in the context of crowdfunding platforms because both project founders and entrepreneurs need to seek early-stage funding from limited resources. Online crowdfunding websites are e-commerce platforms based on the web 2.0 concept, through which all users conveniently create and exchange information. As mentioned earlier, all projects are open on crowdfunding platforms. Therefore, the number of competitors becomes an important concern for crowdfunding project founders. Given the limited resources (funding available) crowdfunding backers have, it is unlikely that each backer will check and contribute evenly to all available projects. As a result, the success of one project will presumably lead to the failure of other projects to reach their funding targets. In other words, competition pressure exists in crowdfunding platforms. Please note that we have simplified the competition scenario in real business practice and do not include non-price competition in this research. Prior research found that a competitive online auction environment will influence bidders' behavior and auction prices [61]. A similar relation was also reported in reviewers' competition behavior for attention in online e-commerce websites such as Amazon [62]. We suggest a similar case exists in the online crowdfunding market, and the number of competitors serves as a signal 
of the competitive environment. Generally, a negative relationship is expected between the number of competitors and the performance of crowdfunding projects. Therefore, we propose the following hypothesis:

Hypothesis 1 (H1). Performance of crowdfunding projects is negatively associated with the number of competitors. The larger the number of competitors is, the lower the performance.

Competition environment is often reflected by another factor: competition intensity. While the number of competitors gives a general idea of the competition environment, competition intensity might present useful information of competition as well such as an effective signal of competition pressure [63]. Existing research shows that competition intensity has significant impact on entrepreneurs' use of resources, thus influencing their economic performance [28] and engagement efforts [29]. High competition intensity might even discourage entrepreneurs from entering a market [26]. In the context of crowdfunding, if several projects arrive at the same time on a platform but with relatively lower funding targets, funders might still contribute to multiple projects in the cases where their budgets allow. On the contrary, if one project enters the platform with a relatively larger funding target, other projects will face intense competition and will probably end up with less support, which renders the factor of competition intensity more salient. We suggest that higher competition intensity makes fundraising more difficult for crowdfunding project founders, especially those that are not well-known. Therefore, we propose the following hypothesis:

Hypothesis 2 (H2). Performance of crowdfunding projects is negatively associated with the competition intensity. The higher the competition intensity, the lower the performance.

Next, we focus on the incentive design, which becomes a critical task for the project founders to motivate contribution in online crowdfunding. One key factor of incentive design is the number of reward levels. In practice, entrepreneurs provide a variety of soft incentives, such as better quality of products, to attract different donors [34]. For rewardbased crowdfunding projects, funders most often only receive non-monetary rewards $[4,36]$. We observe that rewards range from social media cry-out, a hat or a T-shirt with the name of the movie, special IMDB thank credit, and showing the name of the backer at the end of the movie, etc. The crowdfunding model from [39] shows that multiple reward levels help the crowd develop effective learning and adaption. In addition, participants of crowdfunding vary in their evaluation concerning the projects. While some backers would like to contribute several hundred dollars, others might only be willing to contribute $\$ 20$ or $\$ 30$. We propose that the number of reward levels is critical because it often influences funders' contribution decisions. For example, suppose a project founder offers only three levels of rewards which require backer funding of $\$ 10, \$ 100$, or $\$ 1000$. Then potential funders who might contribute $\$ 50$ or $\$ 60$ will only give $\$ 10$ and those who might contribute $\$ 200$ or $\$ 300$ will only give $\$ 100$. On the other hand, a larger number of reward levels is likely to provide more efficient matching of funders and project founders. Consequently, project founders who offer more reward levels will attract more funders and higher contribution amounts. Similar findings were reported in the rental market of digital content [64]. Therefore, we propose the following hypothesis:

Hypothesis 3 (H3). Performance of crowdfunding project is positively associated with the number of reward levels. The higher the number of reward levels, the better the performance.

We suggest that crowdfunding project founders need to consider another factor of incentive design: The contribution level of getting the top reward. Prior research shows that some backers in non-investment crowdfunding platforms are driven by getting the reward $[13,36,65]$. With all rewards of a crowdfunding project listed on the web page, potential funders naturally want to know how to get the top reward offered, especially 
those who have strong preference for the project. However, a relatively high amount might lower potential funders' willingness to get the top reward in the crowdfunding process in spite of their strong personal liking. In addition, an extremely high amount for the top reward might raise concerns, such as whether the quality of the crowdfunding project really matches the target funding or whether it will succeed in the future. Researchers suggest that low expectation of success discourages participants from entering new ventures [35]. Similar findings were also reported in the study from Shneor and Munim, which shows that low-sum backers have a significantly lower quality expectation on the project than highsum backers [66]. We often see that the top rewards asking for extremely high contribution levels such as $\$ 10,000$ or even higher end up with zero backers. As a result, a crowdfunding project with a relatively low contribution level for getting the top reward will be more attractive to potential funders. Therefore, we propose the following hypothesis:

Hypothesis 4 (H4). Performance of crowdfunding project is negatively associated with the contribution level which unlocks the top reward. The higher the contribution level which unlocks the top reward, the lower the performance.

We also examine the impact of attending independent movies festivals as a type of incentive on the performance of crowdfunding projects. Prior research showed that managers can use collective incentives to encourage participants to contribute to collective beneficial action [67]. Attending movie festivals is a suitable common interest/incentive for backers' collective contribution. The theory of community logic also suggests that crowdfunding backers concede a contribution as a form of cooperative capitalism [68,69]. Fisher et al. claimed that when crowdfunding backers are drawn to invest in the project, they consider the decision part of their identity and a commitment to the community [68]. Vismara found that restricted investors follow a community logic when they invest in sustainability-oriented equity crowdfunding [69]. Moreover, participants of online crowdfunding are motivated by multiple incentives other than the rewards offered, such as recognition motivation and image motivation [41]. On the crowdfunding platform, projects targeting movie festivals provide an opportunity for participants to build a reputation of sponsoring high-quality movies, which naturally helps them gain recognition from the community. Studies reported similar findings in the online knowledge community [70] and online idea generation platform [71]. Meanwhile, projects which plan to attend movie festivals often incur additional costs compared with those who do not, such as registration fees, which naturally increase the perception of funding needed and motivate participants to make more active contributions. Therefore, we propose the following hypothesis:

Hypothesis 5 (H5). Performance of crowdfunding projects which plan to attend movie festivals is better than those which do not.

Our hypotheses are summarized in the following conceptual model (Figure 1). Investigating the important drivers of better crowdfunding performance raises interesting theoretical issues. To test these hypotheses, we collected data from an online crowdfunding platform (Seed and Spark) and conducted multiple regression analysis which is to be described in the next section. 


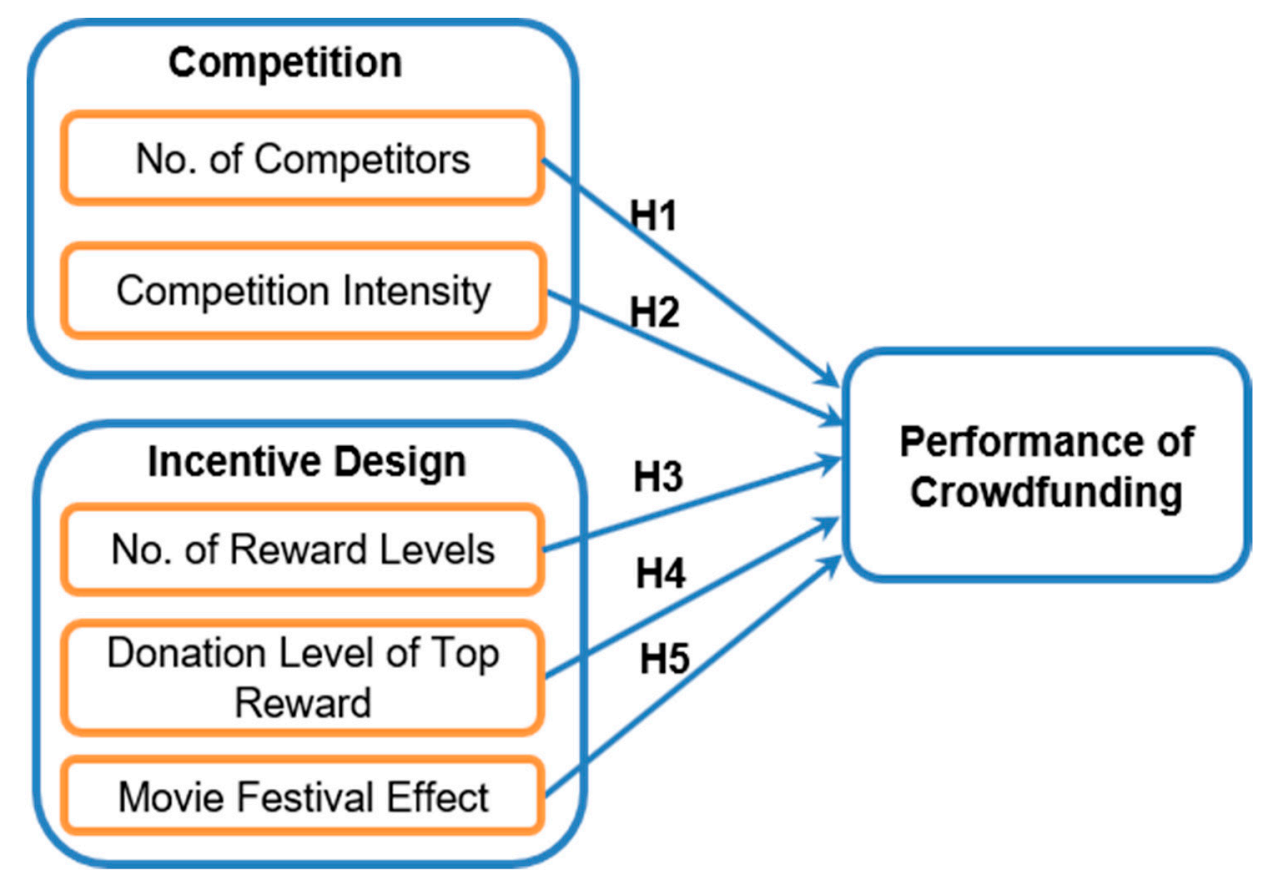

Figure 1. Conceptual Model.

\section{Empirical Analysis}

We present in this section an empirical analysis using real data of independent movie projects to investigate how competition and incentive design might affect the performance of crowdfunding projects. Movies differ from other projects in the following ways. First, the creativity of endeavor of movies focuses on the perspective of entertainment. This is different from technology projects which focus on innovation of new technologies and skills. Second, the outcome of a movie project is in some sense intangible, which is different from tangible outcomes such as food, craft, and fashion. In addition, movie projects usually incorporate verbal, audio, and visual contexts in one project, which is different from other art and cultural projects such as music, dance, photography, publishing, etc.

We choose independent movies for the following reasons. First, raising money is the most difficult task for independent movie producers [72]. Consequently, there might be strong contesting of early-stage funding in crowdfunding platforms, which provides a suitable research setting for our study on the effect of competition. Second, it is estimated that $80 \%$ of movies do not make profit [73]. As a result, potential funders may find it risky to contribute to independent movies. In other words, they might worry that the movie will not be produced even after their contribution. This justifies our analysis to address the dimension of incentive design of crowdfunding projects. Third, independent movies, especially those at the startup stage, do not require a large amount of investment, which is conducive to the application of the crowdfunding model. With crowdfunding gaining popularity, it is not surprising for this line of business to raise money from this model $[74,75]$. We have witnessed several successful cases of movie crowdfunding [76,77].

\subsection{Data}

We collected data from a popular online crowdfunding platform of independent movies and videos: Seed and Spark. This website not only provides a user-friendly platform for aspiring filmmakers to raise money, but is also a place for lovers of independent film web series and film festivals to discover and enjoy. Our dataset includes 209 independent movie projects from June 2019 to October 2019. Prior studies use datasets with similar size. For example, Chintagunta et al. collected a dataset of 148 movies released in the United States [54]. Vismara used a dataset of 271 crowdfunding projects to analyze the effect of social networks in the UK equity crowdfunding market [78]. Wu et al. used 
192 crowdfunding projects to study what factors will attract crowdfunding backers [79]. For each movie project, we collected information from Seed and Spark webpages, which enables us to calculate the values of the dependent variable, independent variables, and control variables for our analysis.

\subsubsection{Dependent Variable}

The dependent variable is the performance of the crowdfunding project, which is measured as the percentage of the amount of funding raised over the funding target. Existing research in the literature often uses funding raised $[13,78]$ or the dummy variable of whether the funding target is reached or not $[12,46]$ as the dependent variable. However, it will largely be influenced by the funding target. Our approach offers a fine-tuned and better measure of performance of crowdfunding projects after controlling the funding target. Moreover, crowdfunding platforms such as Seed and Spark list the percentage on their websites which is easily observable to both project founders and funders.

\subsubsection{Independent Variables}

The independent variables include the number of competitors, competition intensity, the number of reward levels (per thousand dollars), the contribution level of getting the top reward (in log form), and the dummy variable of attending movie festivals. To test Hypothesis 1, we compute the number of competing crowdfunding projects entering the platform on the same day. For example, if there are five projects displayed on the same day, the number of competitors is four. Since Seed and Spark displays projects every day, strong competition exists among movies displayed on the same day. We also tried other time lengths such as one week and the results are similar. To test hypotheses 2 , we define competition intensity as the total target funding of all competitors over the average target funding of all projects. For example, suppose the average target funding is $\$ 10,000$. If there are five projects displayed on the same day, and the total target funding for the other four projects is $\$ 43,000$, then the competition intensity for this movie is 4.3 .

To test Hypothesis 3, we compute the number of reward levels (per thousand-dollar funding target) to control the impact of different funding targets. For example, if one project with funding target $\$ 5000$ offers rewards for six donation levels $\$ 10, \$ 20, \$ 50, \$ 100, \$ 500$, and $\$ 1000$, then the number of reward levels (per thousand-dollar funding target) is 1.2. To test Hypothesis 4, we take the log form of the contribution level of getting the top reward to control the expansion effect. This is a commonly used technique when few records have high values while many others have very low values [64]. This is also consistent with our preliminary observation. To test Hypothesis 5, we use the dummy variable D_Fes which equals one if this independent movie plans to attend movie festivals, and zero otherwise.

\subsubsection{Control Variables}

Additionally, we collect a list of control variables both at the movie level and at the movie producer level. Consistent with the literature, we include movie features such as the duration of the crowdfunding project [13], the number of production team members with a brief introduction [80], and the number of followers in the social network of the independent movie on platforms such as Facebook and Instagram (in log form) [81]. To control the theme of the movies, we classify the movies into three types: drama, comedy, and others. We also created two new dummy variables. D_Drama equals one if the type of the movie is drama and zero otherwise. Similarly, D_Comedy equals one if the type of the movie is comedy and zero otherwise. At the movie producer level, we include the producer's experience in terms of the number of previous projects [14] and two dummy variables to control the gender $[25,82]$ and the location of the producer [24,83]. For example, D_Fem equals one if the producer of the movie is female, and zero otherwise. Similarly, D_CA equals one when the producer of the movie is from the state of California which is well-known for its movie industry, and zero otherwise. Please see Table 1 below for the summary statistics of the collected data. 
Table 1. Summary Statistics.

\begin{tabular}{|c|c|c|c|c|c|}
\hline Variable & Definition & Min & Average & $\operatorname{Max}$ & $\begin{array}{l}\text { Standard } \\
\text { Deviation }\end{array}$ \\
\hline No_Comp & Number of competitors & 0 & 2.517 & 6 & 1.853 \\
\hline Comp_Int & Competition intensity & 0 & 0.872 & 7.442 & 0.809 \\
\hline Level_Rew & Number of reward levels (per $\$ 1000$ of funding target) & 0.11 & 1.170 & 6.154 & 0.888 \\
\hline Log_TopRew & Log of the contribution level of getting the top reward & 4.065 & 7.575 & 11.513 & 1.057 \\
\hline D_Fes & $\begin{array}{l}\text { Dummy variable: } 1 \text { for attending movie festival, } \\
0 \text { otherwise }\end{array}$ & 0 & 0.368 & 1 & 0.484 \\
\hline Duration & Number of days of the project in the platform & 15 & 32.928 & 60 & 6.049 \\
\hline Team & Number of team members with brief introduction & 2 & 6.254 & 20 & 3.446 \\
\hline Log_No_Fol & Log of the number of followers in social network & 2.197 & 5.801 & 9.622 & 1.180 \\
\hline D_Drama & $\begin{array}{l}\text { Dummy variable: } 1 \text { for movie with drama theme, } \\
0 \text { otherwise }\end{array}$ & 0 & 0.292 & 1 & 0.456 \\
\hline D_Comedy & $\begin{array}{l}\text { Dummy variable: } 1 \text { for movie with comedy theme, } \\
0 \text { otherwise }\end{array}$ & 0 & 0.368 & 1 & 0.484 \\
\hline PreProj & Number of previous crowdfunding projects & 0 & 0.158 & 3 & 0.469 \\
\hline D_Fem & Dummy variable: 1 for female producer, 0 otherwise & 0 & 0.574 & 1 & 0.496 \\
\hline D_CA & $\begin{array}{c}\text { Dummy variable: } 1 \text { for producer from California, } \\
0 \text { otherwise }\end{array}$ & 0 & 0.421 & 1 & 0.495 \\
\hline
\end{tabular}

\subsection{Empirical Model}

We use the linear regression model to test our hypotheses because it is a straightforward approach and widely used in the literature $[13,21,78]$. Some previous studies adopt a Probit or Logit model when they use a dummy dependent variable to measure crowdfunding success (the dummy variable equals one if the target funding is achieved, zero otherwise) [12,46]. Since our dependent variable is the percentage of the target funding raised, we consider the regression model an appropriate method. Our regression model is as follows:

Performance $=\beta 0+\beta 1^{*}$ No_Comp $+\beta 2^{*}$ Comp_Int $+\beta 3^{*}$ Level_Rew $+\beta 4^{*} \log _{-}$TopRew $+\beta 5^{*} D \_F e s+$ Control $+\varepsilon$

We have checked the correlation values among those independent variables and control variables used in our model. Table 2 below presents the correlation matrix of independent and control variables. We find that most correlation values are small $(<0.23)$. The only two correlations with absolute value larger than 0.23 are the correlation between two dummy variables D_Drama and D_Comedy $(-0.49)$ and the correlation between the number of reward levels and the log form of the funding amount of getting the top reward $(-0.51)$. We have seen similar absolute values or higher absolute values of correlation in many studies in our reference $[12,18,20,21]$. Overall, our results show that there is no extremely high value that implies too close a relationship.

Additionally, we applied Variance inflation factors (VIF) to check the multicollinearity between independent variables for any undesired effects on the regression results. Since all VIF values are less than 2.0, multicollinearity is not an issue here [13,84]. 
Table 2. Correlation matrix of variables.

\begin{tabular}{|c|c|c|c|c|c|c|c|c|c|c|c|c|c|}
\hline & 1 & 2 & 3 & 4 & 5 & 6 & 7 & 8 & 9 & 10 & 11 & 12 & 13 \\
\hline 1. No_Comp & 1 & & & & & & & & & & & & \\
\hline 2. Comp_Int & $0.12 *$ & 1 & & & & & & & & & & & \\
\hline 4. Log_TopRew & -0.01 & 0.00 & $-0.51^{* * *}$ & 1 & & & & & & & & & \\
\hline 5. D_Fes & 0.05 & -0.07 & 0.03 & $0.13 *$ & 1 & & & & & & & & \\
\hline 6. Team & 0.00 & 0.03 & $0.15^{* *}$ & 0.03 & -0.05 & 1 & & & & & & & \\
\hline 7. Log_No_Fol & 0.03 & -0.04 & $-0.13 *$ & $0.17^{* *}$ & -0.03 & 0.02 & 1 & & & & & & \\
\hline 8. Duration & 0.07 & 0.00 & -0.08 & 0.06 & 0.04 & -0.05 & -0.00 & 1 & & & & & \\
\hline 9. D_Drama & 0.08 & -0.09 & $0.12 *$ & -0.13 * & 0.10 & 0.02 & 0.01 & -0.04 & 1 & & & & \\
\hline 10. D_Comedy & -0.09 & $0.11 *$ & -0.07 & 0.02 & -0.07 & -0.06 & -0.02 & -0.01 & $-0.49 * * *$ & 1 & & & \\
\hline 11. PreProj & -0.02 & -0.07 & 0.06 & -0.02 & -0.02 & $0.22^{* * *}$ & -0.03 & -0.04 & 0.03 & -0.09 & 1 & & \\
\hline 12. D_Fem & -0.06 & 0.05 & 0.04 & -0.05 & -0.04 & -0.11 & -0.06 & -0.06 & 0.00 & $0.16^{* *}$ & -0.06 & 1 & \\
\hline 13. D_CA & 0.06 & 0.02 & $-0.15^{* *}$ & $0.14^{* *}$ & 0.11 & -0.06 & $-0.15^{* *}$ & -0.00 & 0.10 & 0.03 & -0.02 & 0.05 & 1 \\
\hline
\end{tabular}




\subsection{Results}

Our analysis provides comprehensive tests of the impact of factors of competition and incentive design on the performance of crowdfunding projects. To assess the robustness of the hypotheses, we have conducted regression analysis of four models with varying sets of control variables. In Model 1, we only include the five independent variables: the number of competitors, competition intensity, the number of reward levels (per thousand-dollar funding target), $\log$ form of the contribution level of getting the top reward, and the dummy variable of attending movie festivals. In Model 2, we include the five independent variables together with control variables related to movie features: the crowdfunding duration of the project, the number of team members with brief description, log form of the number of followers of the movie in social networks such as Facebook and Instagram and the two dummy variables to control the theme of movie. In Model 3, we include the five independent variables together with control variables of movie producer level: the number of previous projects, the two dummy variables to control the gender and the location of the movie producer. In Model 4, we include the five independent variables together with control variables of both movie level and movie producer level. Table 3 below summarizes the results of our multiple regression analysis.

Table 3. Summary of regression analysis (Standard errors in the parentheses) $\mathrm{N}=209$.

\begin{tabular}{|c|c|c|c|c|}
\hline & Model 1 & Model 2 & Model 3 & Model 4 \\
\hline Intercept & $\begin{array}{c}101.187 \\
(10.677)^{* * *}\end{array}$ & $\begin{array}{c}115.227 \\
(13.218)^{* * *}\end{array}$ & $\begin{array}{c}91.717 \\
(10.699)^{* * *}\end{array}$ & $\begin{array}{c}107.643 \\
(13.356)^{* * *}\end{array}$ \\
\hline No_Comp & $\begin{array}{c}-1.605 \\
(0.621) *\end{array}$ & $\begin{array}{l}-1.459 \\
(0.624) *\end{array}$ & $\begin{array}{c}-1.552 \\
(0.617) *\end{array}$ & $\begin{array}{c}-1.422 \\
(0.622) *\end{array}$ \\
\hline Comp_Int & $\begin{array}{c}-3.049 \\
(1.425)^{*}\end{array}$ & $\begin{array}{c}-3.267 \\
(1.434)^{*}\end{array}$ & $\begin{array}{c}-3.033 \\
(1.417) *\end{array}$ & $\begin{array}{c}-3.238 \\
(1.428)^{*}\end{array}$ \\
\hline Level_Rew & $\begin{array}{c}3.656 \\
(1.499) *\end{array}$ & $\begin{array}{c}3.188 \\
(1.528) *\end{array}$ & $\begin{array}{c}3.528 \\
(1.498) *\end{array}$ & $\begin{array}{c}3.113 \\
(1.528)\end{array}$ \\
\hline Log_TopRew & $\begin{array}{l}-0.254 \\
(1.268) \\
\end{array}$ & $\begin{array}{l}-0.468 \\
(1.292) \\
\end{array}$ & $\begin{array}{l}-0.304 \\
(1.259)\end{array}$ & $\begin{array}{l}-0.536 \\
(1.287)\end{array}$ \\
\hline D_Fes & $\begin{array}{c}7.901 \\
(2.401)^{* *}\end{array}$ & $\begin{array}{c}8.480 \\
(2.415)^{* * *}\end{array}$ & $\begin{array}{c}7.988 \\
(2.394)^{* * *}\end{array}$ & $\begin{array}{c}8.586 \\
(2.414)^{* * *}\end{array}$ \\
\hline Duration & & $\begin{array}{l}-0.320 \\
(0.178)\end{array}$ & & $\begin{array}{l}-0.290 \\
(0.178)\end{array}$ \\
\hline Team & & $\begin{array}{c}0.425 \\
(0.337) \\
\end{array}$ & & $\begin{array}{c}0.388 \\
(0.344) \\
\end{array}$ \\
\hline Log_No_Fol & & $\begin{array}{l}-0.571 \\
(0.981)\end{array}$ & & $\begin{array}{l}-0.325 \\
(0.992)\end{array}$ \\
\hline D_Drama & & $\begin{array}{l}-3.216 \\
(2.906)\end{array}$ & & $\begin{array}{l}-3.434 \\
(2.908)\end{array}$ \\
\hline D_Comedy & & $\begin{array}{l}-0.352 \\
(2.718)\end{array}$ & & $\begin{array}{l}-0.843 \\
(2.742)\end{array}$ \\
\hline PreProj & & & $\begin{array}{l}4.543 \\
(2.420)\end{array}$ & $\begin{array}{l}3.797 \\
(2.480)\end{array}$ \\
\hline D_Fem & & & $\begin{array}{c}4.023 \\
(2.297)\end{array}$ & $\begin{array}{c}4.201 \\
(2.344)\end{array}$ \\
\hline D_CA & & & $\begin{array}{c}1.880 \\
(2.236)\end{array}$ & $\begin{array}{c}1.478 \\
(2.385) \\
\end{array}$ \\
\hline $\begin{array}{l}\text { Adjusted } \\
\text { R-square }\end{array}$ & 0.1166 & 0.1233 & 0.1339 & 0.1360 \\
\hline
\end{tabular}

Notes: ${ }^{* * *} p<0.001,{ }^{* *} p<0.01,{ }^{*} p<0.05$. 
We first examine the impact of competition. Regarding the number of competitors, we find that this factor does significantly and negatively influence the performance of crowdfunding projects ( $p<0.05$ in all four models). Therefore, H1 is supported. This finding implies that the number of competitors should be considered as a key component of project founders' strategy. With limited resources (funding available) in crowdfunding platforms, one project raising more funding often means other projects may end up with less. Khelil regarded competition as an important factor in the profile of failed entrepreneurs [85]. Boone found that the number of competitors can be the proxy of the competition pressure in the market [63]. Project founders need to figure out the best timing to display their projects to maximize the amount of raised funding. A higher number of competitors will motivate funders to decrease the contribution amount to multiple competing projects, thus influencing the performance of the projects. For the platform such as Seed and Spark, a recommendation from this finding is that they can highlight the number of competitors every day on their websites.

We also find evidence which shows that competition intensity is a key driver for the performance of crowdfunding projects ( $p<0.05$ for all four models). The more intense competition pressure is on the platform, the lower the percentage of the funding target that will be raised. It offers support for H2. Our finding implies that competition intensity can be a critical feature of the competition environment for the project founders. Since the funding target of each project each day is easily observed on platforms like Seed and Spark, higher competition intensity appears to signal bad timing of entry and significantly influences funders' willingness to contribute. Agrawal et al. also reported that timing is an important factor for funders' investment decision [24]. Therefore, project founders need to incorporate competition intensity in their crowdfunding strategy to ultimately enhance the chance of crowdfunding success. In case information on competition intensity is not available, project founders can estimate it with the help of historical data to get a better idea of competition on the platforms. Seed and Spark might also consider providing information of competition intensity to help founders and funders who favor an environment with less intense competition.

Next, we examine project founders' strategy of incentive design including the number of reward levels, the contribution level of getting the top reward, and the plan of attending movie festivals. We first check the impact of the number of reward levels. Our results in all four models show that a higher number of reward levels (per $\$ 1000$ funding target) will bring significantly better performance of crowdfunding projects $(p<0.05$ for all four models). It offers support for H3. This finding demonstrates the important role of the number of reward levels in project founders' strategy of reward structure, which is consistent with the optimal design for welfare maximization crowdfunding [39]. When a crowdfunding project provides more levels of rewards, it will provide a better mechanism to satisfy a wider variety of funders' valuation and preference on different movies, which encourages contribution behavior. Our results suggest that project founders might think about adding reward levels to encourage more backers to support their projects.

Regarding the contribution level of getting the top reward, we have seen negative, though not significant, impact in all four models. While the direction of the coefficient is consistent with our Hypothesis, the strength is not. Therefore, H4 is not supported. There may be several reasons for this result. One possibility is that most funders are not interested in the top reward, especially rewards with extremely high contribution levels beyond their budgets. Another possible explanation is that some rewards are similar to the top reward in terms of reward type and description, which reduced the attraction to the funders. For example, we observed that some movie crowdfunding projects in Seed and Spark use similar description for multiple reward levels such as silver, gold, and platinum sponsorship and the top reward (prime sponsorship). A similar finding is reported that contribution level requirements will decrease the success rate in online crowdfunding [4,81]. A recommendation from this finding is that crowdfunding founders might highlight the top rewards to differentiate it from other rewards. 
Next, we analyze the impact of attending movie festivals. Evidence is found that movie festival effect exerts a significant and positive influence on the performance of crowdfunding projects in all four models $(p<0.001)$, so H5 is supported. This finding suggests that movie festivals do attract funders who want to support on the base of common interest and build their reputation on the crowdfunding platform. As a result, more funders will participate as a way to support this project. This is consistent with the finding of the relationship between public incentive and co-funding entrepreneurial projects [33]. In addition, this finding shows that crowdfunding project founders' positive signal of movie creativity and quality (attending movie festivals) help increase the funding perception for that project [86]. Overall, our results have given consistent and significant support to most of the proposed hypotheses. We summarize the results of Hypothesis testing in Table 4.

Table 4. Summary of hypotheses testing results.

\begin{tabular}{lc}
\multicolumn{1}{c}{ Hypothesis } & Support? \\
\hline $\begin{array}{l}\text { H1. Performance of crowdfunding projects is negatively associated with the number of } \\
\text { competitors. The larger the number of competitors is, the lower the performance. }\end{array}$ & Yes \\
\hline $\begin{array}{l}\text { H2. Performance of crowdfunding projects is negatively associated with the } \\
\text { competition intensity level. The higher the competition intensity level, the lower the } \\
\text { performance. }\end{array}$ & Yes \\
\hline $\begin{array}{l}\text { H3. Performance of crowdfunding projects is positively associated with the number of } \\
\text { reward level. The higher the number of reward levels, the better the performance. }\end{array}$ & Yes \\
$\begin{array}{l}\text { H4. Performance of crowdfunding projects is negatively associated with the donation } \\
\text { level which unlocks the top reward. The higher the contribution level which unlocks } \\
\text { the top reward, the lower the performance. }\end{array}$ & No \\
\hline $\begin{array}{l}\text { H5. Performance of crowdfunding projects which plan to attend movie festivals is } \\
\text { better than those who do not. }\end{array}$ & Yes \\
\hline
\end{tabular}

\section{Theoretical Contributions and Practical Implications}

Our study complements prior research in the following three aspects. First, our research enriches the e-commerce literature by extending the analysis of crowdfunding success into competition which is an understudied factor that captures the interaction among crowdfunding projects. Despite the growing interest in identifying factors that influence crowdfunding success, existing research mainly focuses on signaling theory and seeks signals of high quality of projects $[4,13-15,17,19,20,46,81]$. Features of competition among crowdfunding projects have not received much attention. This study, different from most previous research in this area, aims to address this void by exploring the role of competition in the performance of crowdfunding projects. While previous studies mainly focus on competition due to information cascades and competition of entrepreneurs for consumers in the market, our research extends the competition into the early stage of fundraising in which project founders compete for limited resources (funding) to finance their projects. Our results have confirmed an important belief that competition environment appears to be a critical determinant for performance of crowdfunding projects. We expect to see more researchers follow our study. Our findings can be applied to a broad range of online platforms in e-commerce on which project founders compete for limited resources such as funding, attention, non-monetary contribution, etc.

Second, knowing the role of incentive design is significant for both e-commerce researchers and project founders, our research enhances the current understanding of performance of crowdfunding projects by making specific assessments of the impact of project founders' strategy of incentive design. Previous research of reward structure often focuses on extrinsic rewards versus intrinsic rewards. However, many prior findings related to monetary rewards do not apply to reward-based crowdfunding because funders usually receive only non-monetary rewards. This is one of the first attempts to analyze the impact of previously overlooked design features such as the number of reward levels, the 
contribution level of getting the top reward, and public incentives such as attending movie festivals. Our results show the important role of the number of reward levels and the effect of attending movie festivals, which implies the need to expand research on the features of incentive design. Other researchers can start looking at other important but understudied factors of incentive design which will aid project founders on the crowdfunding platform.

Third, we add value to the literature of online movies in e-commerce with the new research direction of crowdfunding. The extant research on online movies usually deals with research questions after the movie is produced such as impact of online reviews on movie revenue [52,54] and online movie piracy [58]. However, fundraising has been a critical challenge for the movie industry, especially for independent movies [72]. Our research provides movie producers with deep and rich insights and helps them make better choices in the environment of crowdfunding in which they engage. This study expands prior research and builds a foundation for future research in this area.

Overall, our research contributes to the e-commerce literature by exploring an overlooked dimension of competition in crowdfunding, adding new features of incentive design as success drivers, and bringing new topics in studies of online movies. Our findings justify the need for continuous research, both theoretically and empirically, into the impact of key factors of competition and incentive design on crowdfunding success.

In addition, our research provides practical implications for e-business starters such as crowdfunding project founders and e-commerce administrators, such as managers of crowdfunding platforms, in the following three aspects. First, our study shows that project founders need to take the competition environment into consideration when they introduce their projects. From a practical standpoint, it is important for them to understand the nature of competition on the platforms where they want to secure early-stage funding. Based on our findings, they might choose to avoid the days when a large number of competing projects display on the platforms or when the competition intensity is extremely high. As for the crowdfunding platforms such as Seed and Spark, they can design better services for information exposure of competition to project founders and backers. For example, they can provide the number of competing projects and an index of competition intensity on the homepage of their websites. Other possible tactics include giving tips related to competition to project founders who first join the platform, answering their related questions, providing the service of checking historical data of competition, etc.

Second, our results show that project founders' better design of rewards will be beneficial. For example, the number of reward levels appears to be an important driver of better project performance. A corresponding recommendation of our finding is that project founders might consider adding reward levels and displaying them more clearly and efficiently on the crowdfunding platform. This can be an effective way to satisfy funders' varied evaluation and encourage contribution. Interestingly, the contribution level of getting the top reward does not show a significant impact although it does have a negative impact. For project founders who want to actively engage participants to donate for the top reward in their projects, they may need to consider strategies to make the top reward more attractive. For example, they may consider revising the description to emphasize the value of the top reward. For the crowdfunding platforms such as Seed and Spark, our recommendation is to provide project founders with guidelines of reward design to help them better prepare their projects.

Third, our analysis finds that attending movie festivals has a positive and significant impact on project performance. This finding implies that non-reward incentives such as setting a specific public goal helps attract funders and justify the funding target. A corresponding recommendation is that project founders might consider highlighting the plans of attending movie festivals in their introduction to promote their projects for more contributions. Project founders also need to carefully design their crowdfunding appeals such as attending movie festivals and create connection ties between their projects and the community of funders [68]. As for the crowdfunding platforms, our results suggest that they can integrate more detailed information of movie festivals and other important 
events in the industry. They may also consider providing the community of participants (both project founders and backers) with better social media discussion on movie festivals. Moreover, we find interestingly that some control variables such as project founders' experience and social capital that are considered signals of quality of crowdfunding projects do not show positive significant impact in our analysis.

Meanwhile, we acknowledge that significant heterogeneity exists among different crowdfunding platforms [25]. Therefore, we need to be cautious when applying our findings to crowdfunding projects of other platforms and industries to avoid potential bias, as suggested by previous studies of crowdfunding success $[25,66,80]$.

\section{Conclusions}

This study is inspired by the growing popularity of online crowdfunding, a new way for new ventures to seek funding to bring their creative ideas to life. While establishing a project is relatively easy on crowdfunding platforms, it is fairly challenging to reach the funding target in the end $[4,11]$. This challenge motivates project founders to identify key drivers of successful projects. Literature of entrepreneurship suggests that competition and incentive design can be critical factors for entrepreneurs to succeed $[23,28,29,33,49,50]$. Nevertheless, these factors are understudied in the extant research on crowdfunding. Our research is a pioneer study to shed light on whether factors of competition and incentive design contribute to the success of crowdfunding projects. Using a unique dataset of 209 crowdfunding projects of independent movies, we are able to carry out a set of regression analyses to test our model.

Our main findings are as follows. First, our empirical analysis suggests that competition (including both the number of competitors and competition intensity) has a significant impact on the performance of crowdfunding projects. The higher competition pressure is, the lower performance crowdfunding projects will be. Second, the number of reward levels contributes to better performance of crowdfunding projects, but the contribution level of getting the top reward does not exert significant impact. Third, attending movie festivals seems to motivate participants' contribution, leading to better performance of projects. Overall, the results from our empirical analysis are consistent with most of our proposed hypotheses.

Our research has a few limitations. First, we have focused on crowdfunding projects of independent movies because the features of independent movie industry make it a suitable setting for our research analysis. However, our dataset is relatively small with 209 crowdfunding projects from one platform (Seed and Spark). While our findings provide useful insights, we do acknowledge that they might be somewhat constrained in terms of generalizability beyond type and the platform of crowdfunding projects. Crowdfunding project founders and backers might have different strategies and behavior on other platforms. Therefore, caution should be taken on potential bias when applying our results across crowdfunding industry and platforms. Second, our analysis assumes that the major resource of funding is from this specific crowdfunding platform (Seed and Spark). We have not considered the possibility of project founders obtaining funding from other resources, which might involve a change of strategies. Finally, our data collection is limited to the level of funders from the crowdfunding platform. For example, we cannot see the funding amount of each backer in Seed and Spark. If the contribution amounts of funders are available to the public, we can expand our dataset in our future studies.

Future research can be extended in the following ways. First, researchers might consider carrying out a cross-type (independent movies and other types of projects such as technology) and cross-platform (small platforms and large platforms such as Kickstarter or Indiegogo) study. They can compare the impact of competition and incentive design on crowdfunding success in those different settings. Online crowdfunding is still in the nascent state. This type of study will strengthen the findings and investigate the role of contextual factors, which can be an interesting extension of our research. Second, as mentioned earlier in the paper, prior studies show that there are two major models for crowdfunding: 
Keep-It-All and All-Or-Nothing. It will be interesting for future research to explore how different models impact crowdfunding founders' strategies of competition and incentive design. Third, future research can investigate incentive design of crowdfunding projects with different types of rewards such as monetary rewards versus affective value rewards. Researchers might also examine the moderating effect of control variables such as funding target and entrepreneur experience. Lastly, future research can consider further exploring competition and incentive design of crowdfunding projects on equity crowdfunding or peer-to-peer lending platforms, which will enhance our understanding of the dynamics of crowdfunding.

Funding: This research received no external funding.

Data Availability Statement: This paper does not use publicly archived dataset.

Conflicts of Interest: The authors declare no conflict of interest.

\section{References}

1. Brush, C.; Greene, P.; Hart, M. From initial idea to unique advantage: The entrepreneurs challenge of constructing a resource base. Acad. Manag. Perspect. 2001, 15, 64-78. [CrossRef]

2. Hellman, T. Entrepreneurs and the process of obtaining resources. J. Econ. Manag. Strategy 2007, 16, 81-109. [CrossRef]

3. Kerr, W.; Nanda, R. Democratizing entry: Banking deregulations, financing constraints and entrepreneurship. J. Financ. Econ. 2009, 94, 124-149. [CrossRef]

4. Mollick, E. The dynamics of crowdfunding: An exploratory study. J. Bus. Ventur. 2014, 29, 1-16. [CrossRef]

5. Business Wire, Crowdfunding Market is Witnesses to USD 89.72 Billing from 2018-2022. 26 June 2019. Available online: https: / / www.bloomberg.com/press-releases/2019-06-26/crowdfunding-market-is-witnessed-to-grow-usd-89-72-billionfrom-2018-2022-technavio (accessed on 25 September 2020).

6. Boeuf, B.; Darveau, J.; Legoux, R. Financing creativity: Crowdfunding as a new approach for theatre projects. Int. J. Arts Manag. 2014, 16, 33-48.

7. Kim, T.; Por, H.; Yang, B. Winning the crowd in online fundraising platforms: The role of founder and project features. Electron. Commer. Res. Appl. 2017, 25, 86-94. [CrossRef]

8. Prolezza, C.; Splendore, S. Accountability and Transparency of Entrepreneurial Journalism: Unresolved Ethical Issues in Crowdfunded Journalism Projects. Journal. Pract. 2016, 10, 196-216. [CrossRef]

9. Simon, R.; Brynildsen, E. Who Benefits from Crowdfunding. Wall Street Journal, 30 March 2016. Available online: https: //www.wsj.com/articles/who-benefits-from-crowdfunding-1459384008 (accessed on 25 September 2020).

10. Robinson, R. 5 Crowdfunded Side Projects that became Million-Dollar Companies. Forbes, 18 September 2017. Available online: https: / www.forbes.com/sites/ryanrobinson/2017/09/18/crowdfunded-side-projects-that-became-million-dollarcompanies/\#7ffe77b53f1d (accessed on 25 September 2020).

11. Prosser, D. Crowdfunding Delivers a 40\% Return and a 40\% Failure Rate. Forbes, 13 September 2016. Available online: https:// www.forbes.com/sites/davidprosser/2016/09/13/crowdfunding-delivers-a-40-return-and-a-40-failure-rate/\#41362bef3473 (accessed on 25 September 2020).

12. Cumming, D.; Leboeuf, G.; Schwienbacher, A. Crowdfunding models: Keep-It-All vs. All-Or-Nothing. Financ. Manag. 2020, 49, 331-360. [CrossRef]

13. Lukkarinen, A.; Teich, J.; Wallenius, H.; Wallenius, J. Success drivers of online equity crowdfunding campaigns. Decis. Support Syst. 2016, 87, 26-38. [CrossRef]

14. Nofsinger, J.; Wang, W. Determinants of start-up firms external financing worldwide. J. Bank. Financ. 2011, 35, 2284-2294. [CrossRef]

15. Block, J.; Hornuf, L.; Moritz, A. Which updates during an equity crowdfunding increases crowd participation? Small Bus. Econ. 2018, 50, 3-27. [CrossRef]

16. Xu, A.; Yang, X.; Rao, H.; Fu, W.; Huang, S.; Bailey, B. Show me the money! In An analysis of updates during crowdfunding campaigns. In Proceedings of the SIGCHI Conference on Human Factors in Computing Systems, Toronto, ON, Canada, 26 April 2014; pp. 591-600.

17. Mitra, T.; Gilbert, E. The language that gets people to give: Phrases that predict success on kickstarter. In Proceedings of the 17th ACM Conference on Computer Supported Cooperative Work \& Social Computing, Baltimore, MD, USA, 15 February 2014; ACM: New York, NY, USA; pp. 49-61.

18. Kromidha, E.; Robson, P. Social identity and signaling success factors in online crowdfunding. Entrep. Reg. Dev. 2016, 28, 605-629. [CrossRef]

19. Colombo, M.; Franzoni, C.; Rossi-Lamastra, C. Internal social capital and the attraction of early contributions in crowdfunding. Entrep. Theory Pract. 2015, 39, 75-100. [CrossRef] 
20. Polzin, F.; Toxopeus, H.; Stam, E. The wisdom of the crowd in funding. Information heterogeneity and social networks of crowdfunders. Small Bus. Econ. 2018, 50, 251-273. [CrossRef]

21. Josefy, M.; Dean, T.; Albert, L.; Fitza, M. Role of community in crowdfunding success: Evidence on cultural attributes in funding campaigns to "save the local theater". Entrep. Theory Pract. 2017, 41, 161-182. [CrossRef]

22. Fanea-Ivanovici, M. Prosumers: Key Factors for Successful Filmmaking Crowdfunding Projects. Int. J. E Serv. Mob. Appl. 2019, 11, 48-60. [CrossRef]

23. Nucciarelli, A.; Li, F.; Fernandes, J.; Goumagias, N.; Cabras, I.; Devlin, S.; Kudenko, D.; Cowling, P. From value chains to technological platforms: The effects of crowdfunding in the digital game industry. J. Bus. Res. 2017, 78, 341-352. [CrossRef]

24. Agrawal, A.; Catalini, C.; Goldfarb, A. Crowdfunding: Geography, social networks, and the timing of investment decisions. J. Econ. Manag. Strategy 2015, 24, 253-274. [CrossRef]

25. Mohammadi, A.; Shafi, K. Gender differences in the contribution patterns of equity-crowdfunding investors. Small Bus. Econ. 2018, 50, 265-287. [CrossRef]

26. Nocke, V. A gap for me: Entrepreneurs and entry. J. Eur. Econ. Assoc. 2006, 4, 929-956. [CrossRef]

27. Spulber, D. Competition among entrepreneurs. Ind. Corp. Chang. 2010, 19, 25-50. [CrossRef]

28. Hernandez-Carrion, C.; Cameraro-lzquierdo, C.; Gutierrez-Cillan, J. Entrepreneurs' social capital and the economic performance of small businesses: The moderating role of competitive intensity and entrepreneurs' experience. Strateg. Entrep. J. 2017, 11, 61-89. [CrossRef]

29. Khan, S.; Tang, J.; Joshi, K. Disengagement of nascent entrepreneurs from the start-up process. J. Small Bus. Manag. 2014, 52, 39-58. [CrossRef]

30. Lin, Y.; Yin, P.; Lee, W.-C. Modeling Dynamic Competition on Crowdfunding Markets. In Proceedings of the WWW '18: 2018 World Wide Web Conference, Lyon, France, 23-27 April 2018; pp. 1815-1824.

31. Kuppuswamy, V.; Bayus, L. Does my contribution to your crowdfunding project matter? J. Bus. Ventur. 2017, 32, 72-89. [CrossRef]

32. Zvilichovsky, D.; Danziger, S.; Steinhart, Y. Making-the-product happen: A driver of crowdfunding participation. J. Interact. Mark. 2018, 41, 81-93. [CrossRef]

33. Arping, S.; Loranth, G.; Morrison, A. Public initiatives to support entrepreneurs: Credit guarantee versus co-funding. J. Financ. Stab. 2010, 6, 26-35. [CrossRef]

34. Glaeser, E.; Shleifer, A. Not-for-Profit entrepreneurs. J. Public Econ. 2001, 81, 99-115. [CrossRef]

35. Monsen, E.; Patzelt, H.; Saxton, T. Beyond simple utility: Incentive design and trade-offs for corporate employee-entrepreneurs. Entrep. Theory Pract. 2010, 34, 105-130. [CrossRef]

36. Gerber, E.; Hui, J. Crowdfunding: Motivations and deterrents for participation. ACM Trans. Comput. Hum. Interact. 2013, 20, 1-32. [CrossRef]

37. Belleflamme, P. Crowdfunding: Tapping the right crowd. J. Bus. Ventur. 2004, 29, 1-16.

38. Chemla, G.; Tinn, K. Learning through crowdfunding. Manag. Sci. 2019, 5, 1783-1801.

39. Ellman, M.; Hurkens, S. Optimal crowdfunding design. J. Econ. Theory 2019, 184, 104939. [CrossRef]

40. Cholakova, M.; Clarysse, B. Does the possibility to make equity investments in crowdfunding projects crowd out reward-based investments? Entrep. Theory Pract. 2015, 39, 145-172. [CrossRef]

41. Bretschneider, U.; Leimeister, J. Not just an ego-trip: Exploring backers' motivation for funding in incentive-based crowdfunding. J. Strateg. Inf. Syst. 2017, 26, 246-260. [CrossRef]

42. Planells, J. Video games and the crowdfunding ideology: From the gamer-buyer to the prosumerinvestor. J. Consum. Cult. 2017, 17, 620-638. [CrossRef]

43. Štofa, T.; Zoricak, M. Selected Success Factors of Crowdfunding Projects. In European Financial System 2016, Proceedings of the 13th International Scientific Conference, Prague, Czech Republic, 13-24 June 2016; Krajicek, J., Nesleha, J., Urbanovsky, K., Eds.; Masarykova University: Brno, Czech Republic, 2016; pp. 752-759.

44. Block, J.; Colombo, M.; Cumming, D.; Vismara, S. New players in entrepreneurial finance and why they are there. Small Bus. Econ. 2018, 50, 239-250. [CrossRef]

45. Block, J.; Groh, A.; Hornuf, L.; Vanacker, T.; Vismara, S. The entrepreneurial finance markets of the future: A comparison of crowdfunding and initial coin offerings. Small Bus. Econ. Forthcom. 2020. [CrossRef]

46. Courtney, C.; Dutta, S.; Li, Y. Resolving information asymmetry: Signaling, endorsement and crowdfunding success. Entrep. Theory Pract. 2017, 41, 265-290. [CrossRef]

47. Parker, S. Crowdfunding, cascades, and informed investors. Econ. Lett. 2014, 125, 432-435. [CrossRef]

48. Vismara, S. Information cascades among investors of equity crowdfunding. Entrep. Theory Pract. 2018, 42, 467-497. [CrossRef]

49. Gneezy, U.; Meier, S.; Rey-Biel, P. When and why incentives (don't) work to modify behavior. J. Econ. Perspect. 2011, 25, 191-210. [CrossRef]

50. Mishra, C.S.; Zachary, R.K. The theory of entrepreneurship. Entrep. Res. J. 2015, 5, 251-268. [CrossRef]

51. Burtch, G.; Ghose, A.; Wattal, S. Cultural differences and geography as determinants of online prosocial lending. MIS Q. 2014, 38, 773-794. [CrossRef]

52. Dellarocas, C.; Zhang, X.; Awad, N. Exploring the value of online product reviews in forecasting sales: The case of motion pictures. J. Interact. Mark. 2017, 21, 23-45. [CrossRef] 
53. Peng, L.; Cui, G.; Li, C. The comparative impact of critics and consumers: Applying the generalisability theory to online movie ratings. Int. J. Mark. Res. 2013, 55, 413-436. [CrossRef]

54. Chintagunta, P.; Gopinath, S.; Venkataraman, S. The Effects of Online User Reviews on Movie Box Office Performance: Accounting for Sequential Rollout and Aggregation across Local Markets. Mark. Sci. 2010, 29, 944-957. [CrossRef]

55. Keh, H.; Ji, W.; Wang, X.; Sy-changco, J.; Singh, R. Online movie ratings: A cross-cultural emerging Asian markets perspective. Int. Mark. Rev. 2015, 32, 366-388. [CrossRef]

56. Koh, N.; Hu, N.; Clemons, E. Do online reviews reflect a product's true perceived quality? An investigation of online movie reviews across cultures. Electron. Commer. Res. Appl. 2010, 9, 374-385. [CrossRef]

57. Lee, Y.; Hosanagar, K.; Tan, Y. Do I follow my friends or the crowd? Information cascades in online movie ratings. Manag. Sci. 2015, 61, 2241-2258. [CrossRef]

58. Jang, B.; Kwak, J.; Lee, B. Empirical Analysis of Factors Influencing Consumer Behaviors in Movie Media Selection: Shifting Demand for Online Movie Piracy to Legitimate Online Media. Int. J. Multimed. Ubiquitous Eng. 2012, 7, 113-122.

59. Hostler, R.; Yoon, V.; Guimaraes, T. Recommendation agent impact on consumer online shopping: The Movie Magic case study. Expert Syst. Appl. 2012, 39, 2989-2999. [CrossRef]

60. Moon, S.; Bergey, P.; Iacobucci, D. Dynamic Effects among movie Ratings, movie Revenues, and Viewer Satisfaction. J. Mark. 2010, 74, 108-121. [CrossRef]

61. Bapna, R.; Chang, S.; Goes, P.; Gupta, A. Overlapping online auction: Empirical characterization of bidder strategy and auction prices. MIS Q. 2009, 33, 763-783. [CrossRef]

62. Shen, W.; Hu, Y.; Ress, J. Competing for Attention: An Empirical Study of Online Reviewers' Strategic Behavior. MIS Q. 2015, 39, 683-696. [CrossRef]

63. Boone, J. Competitive pressure: The effects on investments in product and process innovation. RAND J. Econ. 2000, 31, 549-569. [CrossRef]

64. Chen, L. Retailers' differentiation strategy and pricing in the rental market of digital content: A case of e-textbooks. J. Theor. Appl. Electron. Commer. 2019, 14, 61-75. [CrossRef]

65. Ryu, S.; Kim, Y. A typology of crowdfunding sponsors: Birds of a feather flock together? Electron. Commer. Res. Appl. 2016, 16, 43-54. [CrossRef]

66. Shneor, R.; Munim, Z. Reward crowdfunding contribution as planned behavior: An extended framework. J. Bus. Res. 2019, 103, 56-70. [CrossRef]

67. Seabright, P. Managing local comments: Theoretical issues in incentive design. J. Econ. Perspect. 1993, 7, 113-134. [CrossRef]

68. Fisher, G.; Kuratko, D.; Bloodgood, J.; Hornsby, J. Legitimate to whom? The challenge of audience diversity and new venture legitimacy. J. Bus. Ventur. 2017, 32, 52-71.

69. Vismara, S. Sustainability in equity crowdfunding. Technol. Forecast. Soc. Chang. 2019, 141, 98-106. [CrossRef]

70. Ma, M.; Agarwal, R. Through a glass darkly: Information technology design, identity verification, and knowledge contribution in online communities. Inf. Syst. Res. 2007, 18, 42-67. [CrossRef]

71. Chen, L.; Mardsen, J.; Zhang, J. Theory and analysis of company-sponsored value co-creation. J. Manag. Inf. Syst. 2012, 29, 141-172. [CrossRef]

72. Sullivan, B. How to finance an independent film. Forbes, 8 June 2016. Available online: https://www.forbes.com/sites/ legalentertainment/2016/06/08/how-to-finance-an-independent-film/\#baccec47e346 (accessed on 25 September 2020).

73. Moore, S. Most films lose money! Forbes. Available online: https://www.forbes.com/sites/schuylermoore/2019/01/03/mostfilms-lose-money/\#14cd034f739f (accessed on 25 September 2020).

74. Pozin, I. Crowdfunding: The Future of the Film Industry. Forbes, 20 December 2012. Available online: https://www.forbes.com/ sites/ilyapozin/2012/12/20/crowdfunding-the-future-of-the-film-industry/\#97e9d22c3b6d (accessed on 25 September 2020).

75. Strauss, B. Filmmakers, Turning to Online Crowdfunding to Fund Movies. Daily News, 9 December 2012. Available online: https: //www.dailynews.com/2012/12/09/filmmakers-turning-to-online-crowdfunding-to-fund-movies/ (accessed on 25 September 2020).

76. Wee, H. How equity crowdfunding just might upend film financing. CNBC, 15 May 2013. Available online: https:/ /www.cnbc. com/id/100724191 (accessed on 25 September 2020).

77. Wolfe, A. Stacy Sher' process new Hollywood approach. Wall Street Journal, 30 March 2016. Available online: https://www.wsj. com/articles/stacey-sher8217s-new-hollywood-approach-1389402916 (accessed on 25 September 2020).

78. Vismara, S. Equity retention and social network theory in equity crowdfunding. Small Bus. Econ. 2016, 46, 579-590. [CrossRef]

79. Wu, S.; Wang, B.; Li, Y. How to attract the crowd in crowdfunding? Int. J. Entrep. Small Bus. 2015, 24, 322-334. [CrossRef]

80. Stanko, M.; Henard, D. Toward a better understanding of crowdfunding, openness and consequences of innovation. Res. Policy 2017, 46, 784-798.

81. Zheng, H.; Li, D.; Wu, J.; Xu, Y. The role of multidimensional social capital in crowdfunding: A comparative study in China and US. Inf. Manag. 2014, 51, 488-496. [CrossRef]

82. Harrison, R.; Mason, C. Does gender matter? Women business angels and the supply of entrepreneurial finance. Entrep. Theory Pract. 2007, 31, 445-472. [CrossRef]

83. Lin, M.; Viswanathan, S. Home Bias in Online Investments: An Empirical Study of an Online Crowd Funding Market. Manag. Sci. 2016, 62, 1393-1414. [CrossRef] 
84. Wooldridge, J. Introductory Econometrics: A Modern Approach, 2nd ed.; South-Western College Pub: Nashville, TN, USA, 2002.

85. Khelil, N. The many faces of entrepreneurial failure: Insights from an empirical taxonomy. J. Bus. Ventur. 2016, 31, 72-94. [CrossRef]

86. Davis, B.; Hmieleski, K.; Webb, J.; Coombs, J. Funders' positive affective reactions to entrepreneurs' crowdfunding pitches: The influence of perceived product creativity and entrepreneur's passion. J. Bus. Ventur. 2017, 32, 90-106. [CrossRef] 